\title{
Teachers' Motivational Strategies Used in Indonesian EFL Islamic University Students
}

\author{
Irma Soraya ${ }^{1}$, Fabiola D. Kurnia ${ }^{2}$, Slamet Setiawan ${ }^{3}$ \\ UIN Sunan Ampel Surabaya, Indonesia \\ mozafyr@yahoo.com ${ }^{1}$
}

\begin{abstract}
Captivating EFL learners' attention in a learning process is challenging for every teachers. The teachers must employ appropriate treatment and have motivational strategies to maintain students' enthusiasm in learning. Ample research has been conducted to explore teachers' motivational strategies in teaching English of primary and secondary schools. However, little study has been conducted in university level of students. Therefore, this study is aimed to investigate the use of motivational strategies by teachers in one of the Islamic universities in Indonesia. There were three different teachers as the participants of this research. A qualitative research design was employed to collect the data. Three different groups of students were involved for class observation. The data were collected from teachers by conducting classroom observation, interviews and video recording activity. The finding of the research revealed that each teacher has unique motivational strategies to teach EFL university students. Besides, in the context of Islamic-based university, students get more excited to learn English when the teachers were able to make a connection on English materials, the Islamic values and implication in the real life.
\end{abstract}

Keywords-teachers, motivational strategies, EFL Islamic University students

\section{INTRODUCTION}

Engaging learners in relaxing environment is one of the prominent factors to succeed language learning process. Learners grasp more material contents when they feel comfortable with their classmates, teachers and also the subjects. A huge effort must be carried out by both teachers and learners to achieve the learning goals. The teachers need to create a bridge between the materials and students comprehension in a motivated way so that students' interest is uplifted.

Regarding to the students' interest in language learning, teachers should build students' motivation to promote successful learning. Dornyei (2001) proposed 51 motivational strategies in teaching practice called Motivational Teaching Practice (MTP). It is expected that not only students' motivation increased but also achievement in learning language by applying the MTP. MTP then became popular as teachers' motivational strategies.

There were some studies underpinned teachers' strategies to increase students' motivation in English as Foreign Language (EFL) classroom. The first study conducted in Pakistan by Kakar and Pathan (2017) showed that teachers often applied familiarization L2 related values to students as their strategies to promote learners' autonomy in learning.

The second study by Al qahtani (2016) investigated that macro teaching strategies were frequently used by teachers in Saudi to successfully switch on the students' motivation in learning English. The third study by Astuti (2016) mentioned that teachers of secondary high schools in Indonesia employed these five strategies in class such as to promote teachers' classroom behaviours, supportive classroom atmospheres, selection of learning resources and activities, the usefulness of English, and the way feedback was given.

The aforementioned past studies of teachers' motivational strategies in different level of students and cultural context strengthen that students were highly motivated in learning English when teachers made use of motivational strategies in class. Therefore, the researcher aimed to seek for kinds of motivational strategies used by teachers in EFL Islamic University students and how teachers apply the strategies to students since there have been few studies researching on the context of university level of students. The findings of this study are expected to help English teachers in the university level to understand the source of students' motivation, so that they can implement suitable motivational teaching strategies.

\section{LITERATURE REVIEW}

\section{A. Initiating Learners' Motivation in Language Learning}

Language learners often discouraged when they do not succeed in mastering the materials. There are some factors contributed to students' frustration in EFL classroom one of which is the curriculum design. In most of Islamic universities in Indonesia, English is one of the requisite subjects in completing bachelor's degree of any majors. It is supported by the Indonesian Education Law 19/2005 that English included in the curriculum. The curriculum demand shows that every learner in any majors must take two semesters of English subject. The first semester concerns on improving students skills in oral and written communication. The second semester focuses more to Test of English as Foreign Language (TOEFL) preparation lesson.

The fact that students require to take English lesson for two semesters and pass the exam in order to get certificate to register for oral defence exam somehow creates problems. It is a challenge for teachers to teach English in this condition. Several studies have suggested that motivational factors can influence students' performance (Ryan \& Deci, 2000). 
Another study by You (2004) investigated the positive effect of teaching motivational strategies on students' achievement. The findings depicted students in a friendly environment and high level of self-confidence could achieve their ultimate outcome.

Another study deals with students' ultimate outcome in EFL classroom affected by individual's motivation was conducted by Gardner and Lambert (1959). Students' motivation was controlled by their attitudes and orientation in learning tasks. By showing positive attitudes towards language learning process and having orientation to master the language, students' motivation level and performance automatically increased. Moreover, students' language learning process also corresponds to textbook, classroom activities and the language teachers.

Seeing the importance of language teachers' role in initiating students' motivation, therefore, proper teachers' motivational strategies must be considered to the effectiveness of language learning. Selected motivational strategies that are suitable for EFL university learners and classroom situation are expected to boost students' motivation, accomplishment in completing school requirement for graduation and language mastery.

\section{B. Maintaining Teachers' Motivational Strategies}

Teachers' motivational strategy is a tool to influence students in learning language. Dornyei (2001) defined motivational strategies as a process of motivating individual to achieve plans and reach at certain effect. The MTP framework has been commonly used to investigate the kinds of strategies that teachers used. The MTP framework can be seen in Figure 1 below.

Fig. 1. Components of Motivational Teaching Practice (MTP)

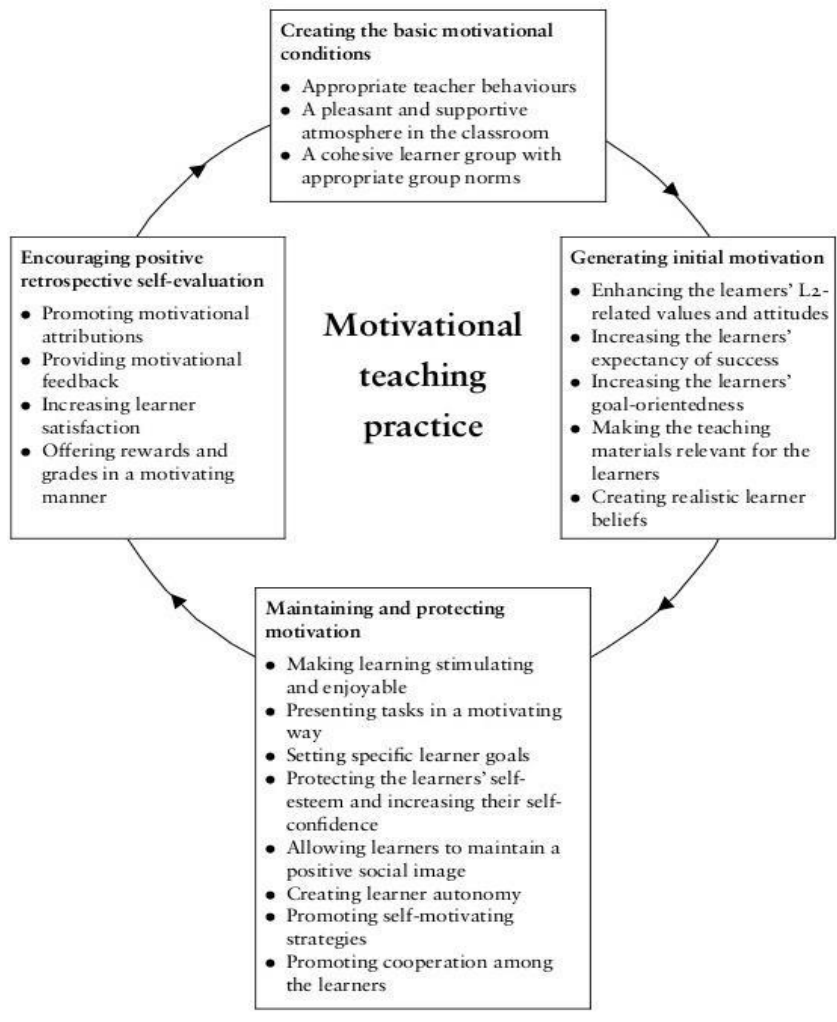

Figure 1 shows that there are four components of teachers' motivational strategies such as creating the basic motivational strategies, generating student motivation, encouraging positive retrospective self-evaluation and maintaining and protecting motivation. Each component has teacher's action to motivate students. Yet, different students' character, environment and teachers' competence make the effect on students motivation varied.

Positive effect on students motivation appears when teachers can suit their strategy to students. Many studies on teachers motivational strategies concur that the key basic to motivational context is the teacher's personality, particularly his or her willingness to be open and share his or her life with students (Nichols, 2014). Besides, Astuti (2016) researched on similar topic. The finding showed that the most influential teachers' motivational strategy was EFL classroom teacher's behaviour. The teacher's behaviour which motivated students reported by Astuti (2016) could be seen from the teacher's smile, facial expression, jokes, and clear instruction in delivering lesson.

Teacher's behaviour seems to give the most effect on students' motivation. More open minded teacher and affectionate can direct students to a better learning environment. Teacher pays attention to students' needs of learning language. This in line with a study by Koran (2014) conducted in Iraq. The result of the study recommended that teacher must investigate the purpose of students in learning language so they can motivate students in such a way. When teachers know their pupils needs, they try to give the most to obtain a better effect on students learning.

A better effect of students learning through teachers motivational strategies could be seen also in a study conducted by Alqahtani (2016). The top rank of motivational strategies was teacher behaviour. The questionnaire in this study related to teacher behaviour included some actions such as showing the students progress, accepting and caring, paying attention and listening to students, showing students that teacher value English as a meaningful experience, trying to have natural, informal conversation with students in class and sharing personal interest to students.

The next most frequently used of motivational strategies according to Astuti (2016) was supportive classroom atmosphere. Meanwhile Alqahtani (2016) ranked supportive classroom atmosphere in the eighth position. The teacher did some of these actions to create pleasant classroom atmosphere such as explaining students' mistakes in leaning language was natural, personalizing learning tasks, letting students expressing ideas freely, giving enough chance to students in discussion, using games, songs and giving religious advice.

Then, both studies (Astuti \& Alqahtani, 2016) exposed that teachers needed to have various learning resources and eventually give feedback. Various learning resources do not merely include materials but also learning techniques and activities in a class meeting. After having some activities, teachers require to give feedback. The way giving feedback must not discourage the students. Teachers could give positive feedback and appraisal, encourage students when making mistakes, etc.

From those previous studies, this study was a replication modified study which investigated the most significant teachers motivational strategies in Islamic-based university. The researcher also wanted to know whether there was 
significance difference on how lecturers implement the motivational strategies to students of EFL Islamic university.

\section{METHOD}

This present study is a replication of Dornyei and Csizer's (1998) as well as Astuti's (2016) investigation. Dornyei and Csizer's research on the perspective of students. Yet, Astuti investigated the teachers of secondary school level. Both studies employed qualitative design. For this reason, this study involved similar research procedures by employing qualitative research design. The method used in this study is a case study to gather richer data on how teachers implement the most frequently used motivational strategies in EFL Islamic university and describe the data briefly (Yin, 2003).

The data collection was gathered from three different lecturers with their students consisting of different study majors such as Mathematics education, English education, Arabic education, etc. The teachers were observed using observation checklist as seen in Appendix 1. While teaching the students, the researcher also recorded the process of learning. Semistructured interviews with teachers were done to dig deeper why teachers selected particular motivational strategies. The obtained data then analyzed in relation to MTP framework by Dornyei (2001).

\section{FINDINGS AND DISCUSSION}

The findings showed that motivational strategies unavoidably play a critical role in maintaining Islamic university students' interest in learning English. There were some motivational strategies used by teachers in each classroom meeting. The strategies applied were showing enthusiasm for teaching and appropriate behaviour, establishing good rapport with students and using various interesting activities. The kinds of motivational strategies that were frequently used by lecturers in EFL Islamic university can be seen in Table 1.

TABLE 1. Teachers' Motivational Strategies in Islamic University Students

\begin{tabular}{|c|c|c|}
\hline No. & Motivational Strategies & Teachers' Action in Classroom \\
\hline 1. & $\begin{array}{l}\text { Showing enthusiasm } \\
\text { \& appropriate } \\
\text { behavior }\end{array}$ & $\begin{array}{l}\text { - Smiling a lot, speaking loudly \& } \\
\text { clearly, giving clear instructions. } \\
\text { - Giving eyes to each side class, } \\
\text { leaving personal activity unrelated } \\
\text { to classroom } \\
\text { - Explaining material clearly, } \\
\text { checking students' understanding. } \\
\text { - Respecting students' questions } \\
\text { positively, trying to give answers } \\
\text { for every question, having no } \\
\text { nervous look. } \\
\text { - Avoiding melancholy look, } \\
\text { avoiding sitting in the desk all the } \\
\text { time, making some jokes. }\end{array}$ \\
\hline 2. & $\begin{array}{l}\text { Establishing good } \\
\text { rapport with students }\end{array}$ & $\begin{array}{l}\text { - Asking students' condition, listen } \\
\text { to students' problems. } \\
\text { - Receiving students' opinion and } \\
\text { complains. } \\
\text { - Saying very good or nice to } \\
\text { students' opinion \& action, giving } \\
\text { verbal rewards. } \\
\text { - Talking about related students' } \\
\text { experiences, relating the topic to } \\
\text { Islamic values. } \\
\text { - Letting students express ideas, } \\
\text { giving enough chances in }\end{array}$ \\
\hline
\end{tabular}

\begin{tabular}{|l|l|l|} 
& & $\begin{array}{l}\text { discussion, giving students' advice } \\
\text { related to spiritual \& religious } \\
\text { things. } \\
\text { • Using L1 to explain difficult topic. }\end{array}$ \\
\hline $3 . \quad \begin{array}{l}\text { Using various kinds of } \\
\text { learning techniques \& } \\
\text { activities }\end{array}$ & $\begin{array}{l}\text { Conducting well-structured } \\
\text { learning activities, implementing } \\
\text { different kinds of techniques, using } \\
\text { songs, creating balance grammar \& } \\
\text { speaking practice. }\end{array}$ \\
\hline
\end{tabular}

\section{A. Showing Enthusiasm for teaching and Appropriate Behavior}

The key factor in how motivating students can be succeeded is teacher's behaviour. From three lecturers' interview and result of observation, lecturers showed high enthusiasm in teaching and appropriate behaviour could get most students' attention. Dörnyei (2001) claimed that every single thing a teacher does in the classroom has a motivational influence on students. At the Islamic universities, students mostly admire and consider their lecturers as their role model.

Becoming a model for students is not an easy job. Those three lecturers usually need to put aside their personal problems as well when teaching. Whatever problems they faced, they kept smiling to show their enthusiasm to students. This way, students felt relaxed and comfortable in learning. Moreover, comfortable learning for students also means that lecturers kept checking on students understanding but in an enjoyable way that students would not feel intimidated by the lecturer's questions. Lecturers also developed a positive relationship with students. Students were more willing to engage in learning activities when there is a positive student and teacher relationship in the classroom (Maulana, Opdenakker, den Brok \& Bosker, 2011). To show positive relationship could be done by checking their students' progress in each learning stage.

Students' progress in learning could also be seen on how they questioned about the materials. Lecturers demonstrated their enthusiasm by positively respected students' questions, gave eyes to every side of class in order not to miss students questions and tried to give the best answer on every question. Students thought that the lecturers valued their learning progress and kept on maintaining their good performance in class.

Overall, lecturers showed their enthusiasm and well behaviour in class to shape students' motivation. They avoided anything that made students afraid of lecturers such as kept smiling, respected personal relationship with students, maintained their emotional problems, and watched students' progress in learning.

\section{B. Establishing Good Rapport with Students}

Lecturers seemed to develop a good rapport to influence students' learning motivation. Good rapport can be in the form of displaying approachable behaviours by coming closer too students, coming side to side to see whether students need help. Since students were mature enough, lecturers rarely got too close to students. Lecturers commented that students felt uncomfortable if they were approached by lecturers with no reasons unless they truly needed help in solving difficult tasks.

Tasks given by lectures should be connected to students' life experience. What interesting was, lecturers gave the tasks by connecting the values of Islamic, prophet life experiences 
with expected students life. Students seemed to understand English materials better when lecturers could make a link of the Islamic values and students life experiences. They were encouraged to finish the English tasks and implemented in their real life.

When students could finish the task, it was also necessary for lecturers to show appreciation and the students' work. Students gradually increased their interest on learning English when the lecturers praised them by saying "very good or nice" towards the students response to the tasks. This is in line to Deniz's (2010) investigation. Lecturers' appreciation to students' effort could motivate students to actively participate in classroom activities.

Challenging tasks that connected to students real life were considered highly motivating by the lecturers. They would eagerly spend more time to accomplish a task that challenged them. Apparently, the integration of technology in the tasks and Islamic values initiated by some of the lecturers was considered as challenging for the students. This is understandable because according to the lecturers, the majority of students' background originally from Islamic boarding schools and now learning in Islamic university where Islamic studies were more comprehensively learned.

\section{Using Various Interesting Activities}

Lecturers employed a variety of interesting activities as their strategy in some meetings. The activities included teaching materials and methods. Besides, they did not rely heavily on the textbooks recommended by the curriculum. Using songs, challenging quizzes in grammar and speaking practice mostly applied by lecturers. In fact, students admired this kind of strategies. They did not get bored in learning.

Different from students, lecturers find it difficult to vary the activities and adapt the materials to meet the need of the student every meeting. They could not afford to set aside time due to their commitment to other workplaces. Another obstacle was their limited access to learning resources in language access center or library. They would share expense to copy materials with the other lecturers and use the copy in turns.

Despite the difficulties in providing interesting activities, there were some readily used materials for learning process, such as listening to songs in the listening practice and watching a short English movie. According to the lecturers, students were excited about experiencing these activities in the classroom and hoped that the lecturers would use these kinds of activities as often as possible.

Teaching activities also deal with teaching methods. Conducting well-structured teaching methods were desired by all lecturers. Actually, a structured and planned teaching process allowed teachers to have an approximate idea of the effort that they need to apply in the teaching process. This sense of control made students less anxious in the classroom because the lecturers could clearly communicate the objectives of learning. The students found it motivating and engaging. Dornyei (2001) mentioned that students engagement in learning activities could lead to students' academic achievement.

\section{Implication of Motivational Strategies in EFL Islamic University Students}

Lecturers implemented those three kinds of motivational strategies in different meetings. Most of those actions worked well and showed good development of students' learning motivation and achievement. It was true from the previous studies and this study that teachers' behaviour became the most influential strategy. Lecturers with good manner, caring, charming and respecting students would likely got the most students' attention in class. Consequently, students brought positive attitudes toward learning English. There were no significance differences on how teachers proved their enthusiasm and appropriate behaviours.

Having high enthusiasm in teaching and appropriate behaviour is not enough for teachers. They also established a good rapport to students. Lecturers worked hard to understand the students. Boundlessness between lecturers and students in EFL classroom could trigger students' free expression in participating in classroom discussion. Lecturers allowed students to share their ideas in group discussion for three to five minutes. The aim of giving the time for each student to talk was to make them brave and speak out loud in every classroom discussion. This obviously was burdensome for students at the beginning. However, the lecturers allowed them to mix their L1 language and English sometimes Arabic. Eventually, students felt less anxious and became more confident in class.

Constructing students' self-confidence could be done in some ways. The majority of students in Islamic university have enough knowledge about religion. Surprisingly, this study captured a unique phenomenon in EFL classroom that slightly different from the other studies. Lecturer could relate Islamic values and inserted to English materials. Students got to talk more in discussion because they were interested in knowing English though the implementation of Islamic values. Even though students' major was not English education, they could share ideas flawlessly.

Lecturers also helped students share ideas flawlessly by having various kinds of techniques and activities. Creative teaching techniques and activities could retain students' memory in such materials. However, some lecturers also complained on varying teaching methods and materials due to their workloads and limited access to sources. It was time consuming to prepare the materials in each meeting. They had an alternative on sharing and exchanging materials with the other lecturers to be used in their classes. They arranged the schedules so that every class had equal chances in enjoying fun learning activities and materials. Additionally, they also integrated technology and Islamic content to classroom.

\section{CONCLUSION}

Lecturers had their own styles in teaching. By mixing and matching motivational strategies in class such as showing enthusiasm for teaching and appropriate behaviour, establishing good rapport with students and using various interesting activities benefitted not only students but also lecturers themselves. EFL Islamic university students enjoyed learning English and showed some progress. Moreover, lecturers were proud of their efforts and students because they could sustain and build students motivation in learning 
English. Such motivation for students leads them to achieve goal of learning and fulfill school requirements. All in all, teachers' motivational strategies could promote students' motivation and achievement.

\section{References}

Alqahtani, S, M, A. (2016). Motivational Strategies and EFL Teachers' Perception: A Saudi Survey. Theory and Practice in Language Studies. 6 (4), 663-674.

Astuti, S, P. (2016). Exploring Motivational Strategies of Successful Teachers. TEFLIN Journal, 27 (1), 1-22.

Csizér, K., \& Dörnyei, Z. (2005). The internal structure of language learning motivation and its relationship with language choice and learning effort. The Modern Language Journal, 89(1), 19-36.

Deniz, S. (2010). Student teachers' evaluation of the motivational strategies used in foreign language teaching. Social Behaviour and Personality: An International Journal, 38(9), 1269-1286.

Dornyei, Z. (2001). Motivational strategies in the language classroom. Cambridge: Cambridge University Press.
Kakar, S, K. \& Pathan, Z, H. 2016. Exploring the Motivational Strategies Practiced by Pakistani EFL Teachers to Motivate Students in Learning English. International Journal of Linguistics, 7 (2), 117-123.

Gardner, R. C., \& Lambert, W. E. (1959). Motivational variables in second language acquisition. Canadian Journal of Psychology, 13(4), 266-272.

Government of Indonesia. (2005). Law No.19/2005.

Maulana, R., Opdenakker, M. C., den Brok, P., \& Bosker, R. (2011). Teacher-student interpersonal relationships in Indonesia: profiles and importance to student motivation. Asia Pacific Journal of Education, 31(1), 33-49.

Ryan, R. M., \& Deci, E. L. (2000). Intrinsic and extrinsic motivations: Classic definitions and new directions. Contemporary Educational Psychology, 25(1), 54-67.

Yin, R. K. (2003). Case study research: Design and methods. Los Angeles, CA: Sage Publications.

You, Z. (2004). The role of motivational strategies in English language learning: an investigation into the relationship between the student language achievement level at Jilin University and their motivational strategies. Teaching English in China, 3, 72-73. 